\title{
Arrest of Ships - The International Conventions on Arrest of Ships
}

\section{Jelena Nikčević Grdinić, Gordana Nikčević}

This paper discusses the most important questions concerning the temporary arrest of seagoing ships through solutions given in the existing international conventions. Special attention is given to the changes contained in the International Convention on Arrest of Ships of 1999 that came into force on 14 September, 2011, compared to the previous Convention of 1952. The basic approach to the principle of temporary arrest of ships remained unchanged according to the Convention of 1999 compared to the 1952 Convention. Still, temporary arrest of ships can only be effected for maritime claims. Having in mind that the 1999 Convention increases the number of maritime claims in relation to the Convention of 1952, and in a way that certain maritime claims that were previously considered claims for purely business relationship, for which creditors had not been able to enjoy the protection relating to arrest of the ship, are deemed to be maritime claims. Changes were also made to the right of re-arrest and multiple arrest of the ship. Convention of 1999 does not greatly alter the existing international regulations as established by the previous Convention, but attempts to additionally specify certain solutions contained in both the Conventions, in terms of their improvement and modernization.

\section{KEY WORDS}

$\sim$ Arrest of ships

$\sim$ Ship

$\sim$ International Arrest Conventions

University of Montenegro, Faculty of Maritime Studies, Dobrota 36, 85330 Kotor, Montenegro

e-mail: jelenag@ac.me

\section{INTRODUCTION}

Arrest of seagoing ships is an issue of considerable importance to the international shipping and trading community. While the interests of owners of ships and cargo lie in ensuring that legitimate trading is not interrupted by the unjustified arrest of a ship, the interest of claimants lies in being able to obtain security for their claims. Arres means the detention of a ship by judicial process to secure a maritime claim, but does not include the seizure of a ship in execution or satisfaction of a judgment. The main objective of the arrest is that the creditor who arrested the ship secures his claims. The final possibility, which stems from the seizure effected, consists of the right to sell the ship in the enforcement procedure.

So far, in the matter of arrest of seagoing ships two international conventions have been adopted. International Convention Relating to the Arrest of Sea-Going Ships of 1952 that came into force on 24 February 1956 and International Convention on Arrest of Ships of 1999 that came into force on 14 September 2011. So far, only 10 states have chosen to ratify this convention and these are Albania, Algeria, Benin, Bulgaria, Ecuador, Estonia, Latvia, Liberia, Spain and the Syrian Arab Republic. However, Denmark and Norway have signed up to the new Arrest Convention and so may choose to ratify it in the future. The 1999 Arrest Convention was designed to update and address the identified deficiencies of the 1952 Arrest Convention and aims to strike a fairer balance between the interests of the ship owner and claimant.

\section{INTERNATIONAL CONVENTION FOR THE UNIFICATION OF CERTAIN RULES RELATING TO THE ARREST OF SEA-GOING SHIPS OF 1952}

\subsection{Determining the number and types of maritime liens}

The basic starting principle is that ships may be only be arrested in respect of securing maritime claims. The Convention 
explicitly lists in its first Article which claims are considered maritime claims. Further, the Convention emphasizes that maritime claims are considered those ones arising out of one of the following causes:

(a) damage caused by any ship either in collision or otherwise;

(b) loss of life or personal injury caused by any ship or occurring in connexion with the operation of any ship;

(c) salvage;

(d) agreement relating to the use or hire of any ship whether by charterparty or otherwise;

(e) agreement relating to the carriage of goods in any ship whether by charterparty or otherwise;

(f) loss of or damage to goods including baggage carried in any ship;

(g) general average;

(h) bottomry;

(i) towage;

(j) pilotage;

(k) goods or materials wherever supplied to a ship for her operation or maintenance;

(1) construction, repair or equipment of any ship or dock charges and dues;

(m) wages of Masters, Officers, or crew;

(n) Master's disbursements, including disbursements made by shippers, charterers or agent on behalf of a ship or her owner;

(o) disputes as to the title to or ownership of any ship;

(p) disputes between co-owners of any ship as to the ownership, possession, employment, or earnings of that ship;

(q) the mortgage or hypothecation of any ship.

Even before the Convention came into force there was no dispute in legislation and court practice of certain maritime countries that the ships may only be arrested for maritime claims. However, when it is needed to determine what is considered a maritime claim, there are basically two approaches. One is that such claims are explicitly enumerated and that out of that enumeration there are no other claims, it is so-called closed list of maritime claims. Another approach is not to enumerate the claims, that is, in addition to possibly enumerated claims, courts can also recognize other claims as maritime ones. This approach is known as open-ended list of maritime claims. ${ }^{(1)}$

Convention of 1952 provides a closed list and in respect of outstanding practice it should concluded that it is about maritime claims that were, as such, undisputed and acceptable to most countries.

1 Tetley states that the Great Britain applies the principle of closed, and Canada the principle of open-ended list of maritime claims. USA also belongs to states having an open-ended list, so it is stated that America belongs among countries with the largest circle of recognized maritime claims.

\subsection{Temporarily arrest of the ship as a method of securing maritime claims}

Definition of the arrest of the ship, as stipulated in Article 1 of the Convention, is that "arrest" means the detention of a ship by judicial process to secure a maritime claim, but does not include the seizure of a ship in execution or satisfaction of a judgment. This type of arrest of the ship in the theory of the Continental Maritime Law is known as the conservative ship arrest, while arrest of the ship on the basis of an enforceable court decision is known as the court arrest. ${ }^{(2)}$

Temporarily arrest of the ship is solely related to maritime claims and can only be pronounced by the court. This does not affect any rights or powers vested in any government, that is any public authority, or in any dock or harbor authority, under any international convention or under any domestic laws or regulations, to detain or otherwise prevent from sailing any ship within their jurisdiction.

Arrest is the security measure that is stipulated in favor of a creditor of maritime claims and its basis represents a personal obligation of the debtor - the owner of the ship in question under certain conditions, and the charterer, or other person responsible for the claim against that ship, though is not its owner. This connection between the maritime claim and the entity responsible for its settlement is reflected in the legal possibility that the Convention provides to a creditor, that for the claim arose out against the ship of the debtor, the creditor may arrest any other ship owned by him, considered to be the ship of the same owner if all its parts belong to the same person.

The exception to this broadly established right to seize another ship belonging to the same owner is made in three cases: disputes as to the title to or ownership of any ship, joint ownership, possession and in relation to the rights of creditors under the mortgage or hypothecation of any ship. The creditor in such cases can solely arrest the ship against which the specific claim arose out. ${ }^{(3)}$

Possibility of arresting another ship belonging to the same owner, i.e. lessee or charterer, depending on who is personally liable for certain maritime claim, is known in legal theory as a "sister ship arrest." This right to seize another ship is recognized today in almost every state, but approach to the matter differs from state to state. Some states, such as, for example, the United Kingdom, allowed the possibility to seize another ship belonging

2 M. Grigoli, Grigoli M., Diritto Della Navigazione, Torino, 1982.str. 495., P. Manca, The Italian Code of Navigation - translation and commentary, 1969, pages 308314 (Articles of the Italian Code from Article 682 to 686).

3 This possibility is stipulated stipulated in Article 3, items 1-4 of the Convention given that excluded claims from seizure of another ship belonging to the same owner are listed in items o, p and q Article1, paragraph 1 of the 1952 Convention. 
to the same owner after adoption of the 1952 Convention. The United Kingdom exercised this right by the Law of 1956, as the literature points out, to comply English law in this matter with continental law countries. The possibility to seize another ship belonging to the same owner was confirmed by the Supreme Court Act of 1981.(4)

Another issue that arises in connection with the "sister ship" clause is the issue of the identity of the ship owner. It may be, in fact, disputable whether in determining the identity only the owner specified on a ship's certificate of registry issued by an Administration (registered owner) is recognized, or the determination process goes further than that, and determines who the beneficial owner (French, véritable propriétaire) is. Most states allow determination of the beneficial owner and attach the rights of the "sister ship" clause to him. ${ }^{(5)}$

The Convention provides a way of proving the existence of a maritime claim and validity of a maritime claim, which would be reason enough to seize the ship. This solution was left to national legislation. According to our law and the laws of most other states, the court shall allow the arrest of the ship if the creditor makes his claim plausible. Additional liability, according to our law, is that a creditor has to justify the arrest effected by filing a lawsuit with the competent court not later than 15 days after permitted arrest of the ship. ${ }^{(6)}$

Arrest of the ship in accordance with the Convention and the legislation of the countries that accept the Convention is of a temporary character. The main objective of the arrest is that the creditor who arrested the ship secures his claims. The final possibility, which stems from the seizure effected, consists of the right to sell the ship in the enforcement procedure. However, the owner of the ship, or other person who uses the ship, may release the ship from the arrest effected, either by paying the debt or by providing an appropriate guarantee for creditors' claims.

Foreign ships cannot be arrested and seized for enforcement during an innocent passage through the territorial sea or internal waters, where an international or intergovernmental regime of navigation is in force. Also, foreign ships cannot be seized and the enforcement procedure cannot be subsequently exercised on them later, if they are retained in the internal waters and ports of our country due to force majeure or the navigation needs while such a need lasts. However, if the foreign ship passing through the territorial sea or internal waters causes a certain damage, for

4 See: F.N. Hopkins, Business and Law for the Shipmaster, Glasgow, 1966, p.60, as well as Article 21 (B item 4 of the Supreme Court Act of 1981).

5 Those states are: Great Britain, France and Canada, whila USA recognizes solely a registered owner.

6 Article 1025, paragraph 2 of the Law on Maritime and Inland Navigation ("Official Gazette of the Federal Republic of Yugoslavia", Nos. 12/98, 44/99, $74 / 99$ and $73 / 00)$. example, pollutes the sea or similar, or it is provided with salvage operations, and in the course of such a sailing a claim against the ship arises due to which normally a seizure can be effected and an enforcement procedure exercised, this ship will be arrested and an appropriate further action will be taken against it. ${ }^{(7)}$

Regarding security, i.e. collateral, which may be given for the release of the ship, in practice this is a security such as a deposit in cash, bank guarantee or a guarantee of R \& I clubs provided that, in addition to the release of the ship, a creditor will be paid the amount which is awarded by the final judgment of the competent court.

A dispute often arises about what nature and the amount of security is sufficient for the court to release the ship and allow the journey to be continued. In accordance with Article 5, paragraph 2 of the Convention, in the absence of agreement between the parties as to, the sufficiency and form of the security, the Court shall have jurisdiction to determine its nature and the amount thereof.

The Convention pays particular attention to jurisdiction for the arrest effected and establishes that the court shall be competent if it is competent also according to its internal law for such an arrest. The court shall have jurisdiction, according to the Convention, if the claimant of the arrest has habitual residence or principal place of business in the State where the arrest has been effected; further, if a maritime claim arose out in the state where the arrest is effected; if a maritime claim arose out during journey in the course of which the arrest has been effected; if a claim arose out of the collision of vessels on the sea due to salvage operations; or if the claim is secured by a maritime hipoteque or mortgage on the arrested ship.

However, the process of arrest due to later litigation procedure is not null and void. The arrest remains in force, and the court determines the period in which the claimant must initiate a proceeding before the competent court or tribunal, and depending on the provisions of the contract of carriage and other circumstances. If the dispute is not initiated in due course, the person whose ship has been arrested may require suspension of a detention and return of the security. Of course, the right according to the Convention applies to states that have ratified the Convention and allow for a possibility that one of the states that have acceded to the Convention denies the right of arrest to claimants who come from states which have not ratified the Convention.

Finally, the Convention stipulates that a request to release the ship and offering of the security according to such a request does not imply recognition of responsibility in relation to maritime claim for which the ship has been arrested.

7 Article 908, paragraph, items 2 and 3 of the Law on Maritime and Inland Navigation . 
In the world naval practice the arrest of the ship is a procedure in which maritime claims may be enforced by a proceeding in rem through forced sale of the ship as the well known institute in common law countries. Therefore, it is one a necessary international legal instrument, through which, in the event that claims are not settled, the forced sale of the ship is provided. This is the advantage that this international Convention provides to the creditors of maritime claims. On the other hand, it protects the debtor, ship owner, lessee (charterer) or other person responsible for the claim against the ship in such a way as to enumerate in Article1, item 1 the maritime claims, thus limiting the right to seize for other types of claims.

\section{INTERNATIONAL CONVENTION OF 1999}

When the IMO, UNCTAD and the CMI initiated proceeding for adoption of the new International Convention on Maritime Liens and Mortgages, the work on preparation of the Convention on the Arrest of Ships was also initiated. This resulted in the adoption of new Convention of 1999. The 1999 Arrest Convention came into force on 2011, having finally been ratified by the requisite ten countries. That this process took over 12 years reflects the lukewarm reception that the Convention has received from the international shipping community. ${ }^{(8)}$

The new Convention from 1999 also does not greatly alter the existing international regime as established by previous Convention, but seeks to codify the whole matter, leaving less space to Contracting States for "their own solutions." However, as regards enforcement of the arrest procedure, it is still left to national legislation by application of the principle lex fori.

The basic approach to the principle of temporary arrest of ships remained unchanged according to the Convention of 1999 compared to the 1952 Convention. Still, temporary arrest of ships can only be effected for maritime claims. Having in mind that the 1999 Convention increases the number of maritime claims in relation to the Convention of 1952, and in a way that certain maritime claims that were previously considered claims for purely business relationship, for which creditors had not been able to enjoy the protection relating to arrest of the ship, are deemed to be maritime claims. Namely, while in the 1952 Convention all claims, which are considered maritime, are classified in 17 groups from a to q, maritime claims in the 1999 Convention are contained in 22 groups starting from a and ending with v.

In accordance with Article 1 of the Convention "Maritime claim" means a claim arising out of one or more of the following:

8 Article 14 of the 1999 Arrest Convention provides that it will enter into force six months after it has been ratified by 10 States. Albania became the tenth State to ratify the Convention on 14 March 2011.The States which have agreed to be bound by the Convention are Albania, Algeria, Benin, Bulgaria, Ecuador, Estonia, Latvia, Liberia, Spain and the Syrian Arab Republic. loss or damage caused by the operation of the ship; loss of life or personal injury occurring, whether on land or on water, in direct connection with the operation of the ship;salvage operations or any salvage agreement, including, if applicable, special compensation relating to salvage operations in respect of a ship which by itself or its cargo threatened damage to the environment; damage or threat of damage caused by the ship to the environment, coastline or related interests; measures taken to prevent, minimize or remove such damage; compensation for such damage; costs of reasonable measures of reinstatement of the environment actually undertaken or to be undertaken; loss incurred or likely to be incurred by third parties in connection with such damage, and damage, costs or loss of a similar nature to those identified in this subparagraph (d); costs or expenses relating to the raising, removal, recovery, destruction or the rendering harmless of a ship which is sunk, wrecked, stranded or abandoned, including anything that is or has been on board such ship, and costs or expenses relating to the preservation of an abandoned ship and maintenance of its crew; any agreement relating to the use or hire of the ship, whether contained in a charter party or otherwise; any agreement relating to the carriage of goods or passengers on board the ship, whether contained in a charter party or otherwise; (h) loss of or damage to or in connection with goods (including luggage) carried on board the ship; (i) general average; (j) towage; (k) pilotage; (1) goods, materials, provisions, bunkers, equipment (including containers) supplied or services rendered to the ship for its operation, management, preservation or maintenance; $(\mathrm{m})$ construction, reconstruction, repair, converting or equipping of the ship; ( $n$ ) port, canal, dock, harbour and other waterway dues and charges; (o) wages and other sums due to the master, officers and other members of the ship's complement in respect of their employment on the ship; including costs of repatriation and social insurance contributions payable on their behalf; (p) disbursements incurred on behalf of the ship or its owners; (q) insurance premiums (including mutual insurance calls) in respect of the ship, payable by or on behalf of the shipowner or demise charterer; $(r)$ any commissions, brokerages or agency fees payable in respect of the ship by or on behalf of the shipowner or demise charterer; (s) any dispute as to ownership or possession of the ship; $(t)$ any dispute between co-owners of the ship as to the employment or earnings of the ship; $(u)$ a mortgage or a "hypotheque" or a charge of the same nature on the ship; (v) any dispute arising out of a contract for the sale of the ship.

In relation to the 1952 Convention the claim from bottomory was the only one omitted, and the following claims were added: claims for indemnification or other compensations in connection with elimination of perils or preventive actions, claims in connection with pollution of the marine environment or similar actions regardless of whether they arose in relation to international conventions or any other regulations or 
agreements. This obviously introduced compensation and rewards for prevention and elimination of damages caused by pollution of the marine environment as maritime claims.

Likewise, maritime claims are considered the costs associated with the lifting, removal or destruction of the remains of the ship and cargo, which was not foreseen by the Convention of 1952. The Convention, following solutions of the 1993 International Convention on Maritime Liens and Mortgages, supplements the rights of seamen for protected maritime claims, considering the right for costs of repatriation and social insurance contributions payable on their behalf as maritime claims.

Likewise, as already mentioned, maritime claims are considered port, canal, dock, harbor and other waterway dues and charges, as well as claims from insurance premiums including mutual insurance calls (contribution to P\&l clubs), and agency fees in respect of the ship, payable by or on behalf of the shipowner or demise charterer.

In the first comments that appeared after the adoption of the Convention of 1999, it was considered that in relation to the application of sister ship clause on arrest of another ship belonging to the same owner, the Convention narrows that right in a way that only another ship of a registered owner and not of beneficial owner may be seized, as so far has been the case in the current practice in most states. Such a solution of the new Convention has already been criticized in the literature. ${ }^{(9)}$ The conclusion reached by Tetley in the quoted article is only possible based on intentions of participating countries at the conference where the Convention was adopted, to narrow the existing approach to the sister ship clause. But, in respect of grammatical interpretation of the new text of the Convention, we deem that there is no basis for the conclusion that the Convention changes the existing approach. The attitude of the case law, and after the entry into force of the Convention, should show whether in this respect changes in basic approach to this matter occurred. We think that still nothing prevents the courts to allow for determination of the real ownership of the ship, and that all ships belonging to the beneficial owner may be seized for collection of maritime claims. ${ }^{(10)}$

In relation to the extensions made, a classification of owed insurance premiums and agency fees among maritime claims should be certainly considered the great innovation, because up to now there has been an attitude, both in theory and in the

9 W. Tetley, Arrest, Attachment and Related Maritime Law Procedures (1999), 73 Tulane Law Review 1895-1985, points to a diference between 1952 Convention and the same Article of 1999 Convention, consisting of wordings "owned by" in the original text, and wordings "owner of the ship" in the text of 1999

10 As the Convention relatively recently came into force, it cannot be determined with certainty whether the case law in all states will follow formal legal opinion on ownership of the ship, or will, as so far has been done, allow the probate proceeding of real ownership of a certain ship in each individual case. case law, that it is about purely commercial claims, which cannot be settled by the possible seizure of the ship. Likewise, disputes under ship purchase and sale agreement, until adoption of the 1999 Convention, were considered to be purely economiccommercial disputes, and eventually such a claim could not be obtained by the seizure.

Extensions which the Convention accepts take the output of the Convention go out to meet, on one hand, the new international regulations in the field of protection of the sea and the marine environment, and on the other the case law of many states that have already recognized port, canal, dock, harbor and other waterway dues and charges as maritime claims.

Unlike the 1952 Convention, the 1999 Arrest Convention allows claimants multiple opportunities to secure their claims. Under Article 5, a claimant can re-arrest a ship after it has been released, and has the option of arresting multiple ships, in order to top up the security for his claim. The right to re-arrest or to arrest multiple vessels arises only when:

- $\quad$ the security already provided is inadequate (in the case of re-arrests, the security can never exceed the value of the vessel in question);

- $\quad$ or the person who provides the security is not, or is unlikely to be able to, fulfill its obligations;

- $\quad$ or the ship or the original security was released either with the consent of the claimant acting on reasonable grounds or because he could not by taking reasonable steps prevent the release.

It is certain that the proposed solutions in the Convention go out to meet the commercial participants and intermediaries in maritime navigation, such as insurers, agents, banks, and especially banks providing loans for shipbuilding and sale of ships. In its remaining part, the Convention just further specifies the solutions adopted also by the Convention of 1952.

The Convention stipulates the possibility in cases if arrest of the ship having been wrongful or unjustified, or where excessive security having been demanded and provided by the a creditor of the arrest, that the courts may impose upon the claimant who seeks to arrest or who has procured the arrest of the ship the obligation to provide security of a kind and for an amount, and upon such terms, as may be determined by that Court for any loss which may be incurred by the defendant as a result of the arrest. This solution is in accordance with the existing case law in many states. In the South African Republic, courts, almost without exceptions, require that the creditor, which requires arrest of the ship, has to deposit the security determined by the court in order to allow the arrest.

Both Conventions provide for prohibition of rearrest, i.e. multiple seizures of the same ship or another ships belonging to the same owner in the territory of states that have ratified the Conventions and apply the same. Arrest of the ship shall 
be determined by application of the law of the state where the arrest was effected. The condition for arrest in the procedure law context is that the ship whose arrest is sought is within the jurisdiction of the state concerned and the particular court. In this matter, it is irrelevant whether or not cargo or passengers are on the ship, and whether or not the ship is ready to sail. The arrest may be imposed until the last moment while the ship, for which the arrest was sought, is within a jurisdiction of maritime and legal authorities of the state where the arrest is sought. However, the ship that is passing through the territorial sea and other waters may not be arrested. The basis for arrest possibility is harbor entrance.

It has been said that the question of jurisdiction to decide on arrest of the ship is not related to the issue of actual judicial or arbitral jurisdiction for judging in the dispute for the claim for which arrest is sought. In that part there are certain differences between the 1952 Convention and the 1999 Convention. The 1952 Convention, in Article 7, explicitly enumerates cases where the court of the state in which the arrest is effected shall have jurisdiction to determine the case upon its merits. ${ }^{(11)}$ If the court which imposed the arrest is not competent for judging of the dispute in question, the court will accept agreement of the parties to submit the dispute to a court of another state which accepts jurisdiction, or to arbitration, or will, in the absence of such agreement, determine the period within which the claimant should initiate proceeding before the competent court or arbitration and thus condition the validity of the arrest, i.e. deposited security. 1999 Convention goes further than this solution, and the court of the state that allowed the arrest, is declared competent to accept the trial for a dispute due to which the arrest was effected. However, this provision does not prejudice the right of parties to entrust their dispute to the court or arbitration of another state, or to the local court of the state, even if the court declared itself incompetent in accordance with the norms of domestic law. If there is no valid agreement the court will accept the dispute or give a specific deadline to litigants, i.e. the claimant, to initiate proceeding before the competent court or arbitration tribunal, and all with the legal consequences as it is standardized under the 1952 Convention.

11 The Courts of the country in which the arrest was made shall have jurisdiction to determine the case upon its merits if the domestic law of the country in which the arrest is made gives jurisdiction to such Courts, or in any of the following cases namely: (a) if the claimant has his habitual residence or principal place of business in the country in which the arrest was made; (b) if the claim arose in the country in which the arrest was made; (c) if the claim concerns the voyage of the ship during which the arrest was made; (d) if the claim arose out of a collision or in circumstances covered by article 13 of the International Convention for the unification of certain rules of law with respect to collisions between vessels, signed at Brussels on 23rd September 1910; (e) if the claim is for salvage; (f) if the claim is upon a mortgage or hypothecation of the ship arrested.

\section{CONCLUSION}

Our country ratified the 1952 Convention. During ratification, it used the right to enter a reservation not to apply the provisions of the Convention, but its own right when it comes to disputes about ownership of the ship. It was then understandable considering the so-called state (public) ownership of ships in that period. However, that reason is not valid any more. In the remaining part, the Convention was ratified without reservations, which included its implementation as a whole, with no additional changes or modifications. The right to arrest the ship is incorporated in our law and is still in the Law on Maritime and Inland Navigation, which represents a positive piece of legislation in Montenegro. Although Montenegro, following its independence, started creating a new maritime legal framework in a way that certain areas of the Law on Maritime and Inland Navigation are to be separated and regulated by special laws, a new legislation in this matter has not been adopted yet. In addition, we believe that, although Montenegro has not ratified the 1999 Convention, it would be useful to take into account and to accept a solution which that Convention provides as the protection of ship owners from excessive claims of creditors during the arrest of ships.

\section{REFERENCES}

Berlingieri, F., (2000), Arrest of ships, A commentary on the 1952 and 1999 Arrest Conventions, third edition, London, Hong Kong.

Bolanča, D., (1996), Privremene mjere kao mjere osiguranja u hrvatskom pomorskom zakonodavstvu, Pravni vjesnik 12(1-4), pp. 96-105.

Ćorić, D., (1990), Međunarodna unifikacija pravila o postupku privremene mjere zaustavljanja broda, Uporedno pomorsko pravo i pomorska kupoprodaja, v.32 (12), Zagreb.

Grabovac, I., (1995), Hrvatsko pomorsko pravo i međunarodne konvencije, Split.

Grigoli, M., (1982), Diritto Della Navigazione, Utet.

Hopkins, F.N., (1966), Business and Law for the Shipmaster, Glasgow.

Ivković, Đ., (2005), Međunarodna konvencija za izjednačenje nekih pravila o privremenom zaustavljanju brodova, 1952, Priručnik, Piran, available: http://www. dpps- mlas.si/ivkovic/ (accessed: 10 April 2012).

Ivković,Đ., (2006), Privremene mjere na brodu, Priručnik, Piran, available: http:// www.dpps- mlas.si/ivkovic/ (accessed: 10 April 2012).

Manca, P., (1969), The Italian Code of Navigation - translation and commentary, A. Giuffré, 1958, Milano.

Marin, J., (2003), Privremene mjere zaustavljanja broda, PhD Thesis, Zagreb: Faculty of Law in Zagreb.

Pavliha, M., Grbec, M., (2002), Abeceda pomorskega prava in zaèasna zaustavitev ladje, The «ABC» of Maritime Law and Arrest of Ships in Slovenia", Ljubljana.

Tetley, W., (1999), Arrest, Attachment and Related Maritime Law PProcedures, Tulane Law Review, 73, pp. 1895-1985. 